Editorial

\title{
Norms, Institutions and Governance in an Era of Uncertainty: Connecting the Disparate Scholarship
}

\author{
Russell Alan Williams ${ }^{1, *}$ and Reeta Chowdhari Tremblay ${ }^{2}$ \\ ${ }^{1}$ Department of Political Science, Memorial University, St. John's, NL A1B 3X9, Canada; E-Mail: russellw@mun.ca \\ ${ }^{2}$ Department of Political Science, University of Victoria, Victoria, BC V8W 2Y2, Canada; E-Mail: reeta@uvic.ca \\ * Corresponding author
}

Submitted: 8 August 2016 | Published: 11 August 2016

\begin{abstract}
This thematic issue sprung from a desire to encourage more dialogue across subfields in the study of politics and governance on how we understand the emerging practices of global governance. Shifts in global power, the emergence of new organizations and regimes and the ever-increasing complexity of interstate cooperation have all contributed to increased interest in "governance" and the role supranational organizations play in managing globalization, regionalization and regional integration. They have also contributed to increased theoretical diversity in how "governance" should be studied. While international politics scholars, drawing on constructivist literature, have placed considerable emphasis on the development and diffusion of norms; others have drawn on the insights of comparative politics, public policy and political economy to study similar issues. While the legacy of older disciplinary boundaries continues to isolate new theoretical developments, it is clearly the case that there is a high degree of complementarity in the study of governance, particularly in the emphasis on "norms" or "ideas" and their level of institutionalization.
\end{abstract}

\section{Keywords}

comparative politics; governance; institutions; international organizations; international relations; norms

\section{Issue}

This editorial is part of the issue "Supranational Institutions and Governance in an Era of Uncertain Norms", edited by Russell Alan Williams (Memorial University, Canada) and Reeta Tremblay (University of Victoria, Canada).

(C) 2016 by the author(s); licensee Cogitatio (Lisbon, Portugal). This article is licensed under a Creative Commons Attribution 4.0 International License (CC BY).

"It was the best of times, it was the worst of times" Charles Dickens, A Tale of Two Cities, 1859

\section{Introduction}

For scholars pursuing the study of global governance, this is indeed, both the "best" and "worst" of times. We are awash in exciting and challenging topics for study; the crisis in EU governance, "Brexit", the global climate change policy negotiations, the shortcomings of the global trade regime, endemic financial crises, Human rights and "R2P" and the integration of emerging powers into the existing institutional ensemble. However, as we try to understand the increasing complexity of our multilevel political systems, we are also confronted with ever-increasing theoretical and methodological pluralism. As Holzscheiter, Bahr and Pantzerhielm (2016) put it in this thematic issue, "In global governance scholarship, it is an almost ritualistic acknowledgement that contemporary international relations are characterized by an escalating institutional fragmentation, competing/intersecting spheres of authority and the resulting pluralism of norms, rules and implementation structures." In our efforts to make sense of the vast challenges of governance, we do so from a variety of perspectives; perspectives that we argue here are inherently complimentary, if somewhat academically disconnected. This thematic issue attempts to connect a variety of approaches to global governance as part of plea for cross-disciplinary dialogue on how 
governance operates in contemporary world order.

When we initially issued the call for papers, we expected to get a mixture of two kinds of articles. Some, coming from an international relations (IR) perspective, would inevitably deploy constructivist approaches to the development of norms and institutionalization (Barnett \& Finnemore, 2004; Checkel, 1998). A second group, we hoped, would spring form more traditional comparative politics concerns about federalism, representation and more norms-based or discursive approaches to the study of comparative public policy. While the response we received was deep, what we have ended up with is far more complex than we originally hoped for, highlighting our basic concern; a wide variety of scholarship is talking about "global governance" or "supranational politics", but it in a disconnected way.

\section{Understanding Global Governance}

The challenges are two fold to the study of global governance. On the one hand, we continue to struggle with the legacy of the "levels of analysis" problem so central to the last forty years of scholarship on politics and international relations. While much of the study of global governance has emerged from International Relations scholarship, reflecting its longstanding commitment to the challenges of cooperation and interstate relations in an environment lacking formal mechanisms of government, increasingly the problems of governance, be they challenges of implementation at the domestic level, the creation of more effective and responsive institutions, and basic questions about the accountability of the global and regional organizations, draw analysis closer to issues traditionally encountered in comparative politics.

Relatedly there is also the challenge of "scope". While some study global institutions, others focus and specialize narrowly on regional institutions. Others go further, exploring the problem at the domestic level, asking questions about how global norms etc. are institutionalized within national settings. Interestingly, the domestic level focus often draws on international relations theory to explain failures in implementation, rather than tools more clearly developed for the domestic political setting.

We have a conceptual and theoretical diversity. While this can be fruitful, generating the new ideas necessary to grapple with the world "as it is", the point here is that much of the work tends to only speak to isolated groups of scholars with shared theoretical and methodological commitments. As is illustrated in this issue, work from alternative approaches can offer challenging new insights to our own modes of study.

\section{The Contributions}

Despite considerably different theoretical commit- ments the contributors to this volume do offer an overarching theme in how we should study (and practice, for the matter) global governance. On the one hand, all of the articles highlight the role of "norms" (variously labelled) as being crucial to "effective" governance. On the other hand, they all also highlight the role that institutional design plays in facilitating the development of shared norms.

\subsection{The Contribution from International Politics}

As alluded to above, Holzscheiter et al. (2016) offer a big picture assessment of how we should think about global governance from an IR "constructivist" perspective. In their careful examination of international organizations involved in global health, they argue that despite considerable scope for fragmentation given haphazard institutional arrangements there has actually been considerable convergence across organizations due to the existence of an overarching "metagovernance" provided by a shared normative commitment to "order" and "harmonization" among these groups. They offer both a typology for thinking about these metagovernance norms (Jessop, 2014, Wiener \& Puetter, 2009) and important insights on how we might approach the challenge of fragmentation. For example several of the articles coming out of comparative politics literatures, highlight the absence of these kind of shared metagovernance norms in explaining organizational and institutional failures.

Likewise, expanding on her own considerable contribution to the constructivist literature, Antje Wiener's (2016) article offer a unique and challenging case study on the management of the North Atlantic fishery. Working in a context where state's positions were initially deeply rooted in national interests, and contestation was all too familiar to traditional students of foreign policy, Weiner illustrates that over time what emerged was a more cooperative and shared set of norms about what constituted good fisheries management. While the article illustrates the considerable power of Weiner's particular approach to the study of norms, it also illustrates concerns central to the comparative public policy literature (below); "getting to agreement" requires careful attention to the institutional process used to engage stakeholders. As Weiner illustrates, resolving conflict over fisheries in this case could have been accelerated by promoting more direct stakeholder involvement in management.

Finally, Carla Barqueiro, Kate Seaman and Katherine Towey's (2016) examination of regional security organizations' adaptation of Responsibility to Protect (R2P) norms is a compelling (and topical) illustration of the power of the constructivist approach to international institutions. Drawing on Finnermore and Sikkink's (1998) concepts about norm life cycle "localization" they offer an in depth analysis of how the EU, the 
League of Arab States and the African Union have deployed different ideas about R2P in relation to the Libyan and Syrian civil wars. Pessimistically, they argue these differences only render R2P even less effective from the perspective of ensuring, "timely and decisive responses to protect civilians". While they suggest that the key cause has been a level of politicization within the organizations, their account highlights the role of both norms and institutional arrangements in support of those norms in the on-going politics of R2P.

\subsection{The Contribution from Comparative Politics}

Meng Hsuan Chou, Michael Howlett and Kei Koga (2016) offer an alternative approach to assessing the success of international institutions; one that comes squarely out of the comparative public policy literature on policy failure and the role of institutional design and organizational capacities in facilitating "learning" in response to policy problems (Streck \& Thelan, 2005). Through a careful examination of ASEAN's struggles with security cooperation and the EU's challenges in relation to migration, they argue that there are really two kinds of policy failures encountered in international organizations, substantive failure relating to the shortcomings of existing policies and more basic failures relating to conflicts over policy image within organizations. While the article is a novel and challenging new way to think about governance, the emphasis on "drift" in policy image echoes many of the concerns raised in the constructivist IR literature about norms. This complimentary focus on norms is also echoed in the key takeaway from their article: that successful governance requires (first and foremost) successful institutional design and capacities if organizations are going to be able to address policy failures.

Drawing on the rich political economy literature, which has been grappling with its own concerns about global governance for a long time, Robert Finbow (2016) offers his insights. While examining recent developments in investor to state dispute resolution systems, Finbow argues (Cerny ,1997; McBride, 2006) that the growth in these governance mechanisms expands the powers and interests of economic elites at the expense of national governments. While the political economy literature has always been sensitive that not all global governance is necessarily "good governance" the real lesson provided by Finbow, is that we have reached a point where we require new thinking about the basic intellectual underpinnings of the "democratic state", a challenge not often made clearly in the IR literature.

Finbow's concerns are echoed by David P. Rapkin, Jonathan R. Strand and Michael W. Trevathan (2016). Another "comparative politics" based analysis of global governance, drawing on the traditions of normative political theory and its considerable insight on the meaning and substance of representation, Rapkin et al.
(2016) argue that global governance has a more basic challenge than simply tinkering with different forms of engagement to facilitate learning. Instead, they argue that scholars working in this area need to think more deeply about representation itself. Through a case study on the governance structures of the International Monetary Fund (IMF) they illustrate how limited and contradictory ideas about representation are in these type of venues. To put it in words borrowed from the constructivist literature, these organizations lack "metagovernance" norms about things as basic as representation. Rapkin et al. (2016) argue that without greater clarity on these issues international organizations are unlikely to be effective.

\subsection{The Contribution from the Study of "Domestic" Politics}

Valerie J. D'Erman's (2016) article on the CanadaEuropean Union trade negotiations of CETA draws on insights from the comparative federalism literature in effort to understand the normative status of EU trade institutions. D'Erman challenges us to think about EUlevel governance on this one topic in comparison to governance within a federal state (Canada). Her key point, running counter to much of the current malaise about EU institutions is that in practical terms, EU trade policy is more "integrated" at the supranational level than it is in Canada, and more to the point, that it enjoys a unique level of normative legitimacy. While D'Erman's article suggests important lessons for the "success" of the EU project, it also suggests the need to move the study of the EU to something more closely approximating how multilevel governance is studies in other federations. Indeed, Amy Verdun (2016) offers a similar but wider reaching analysis of this comparison in her article. Verdun puts the case more bluntly, asking whether we should be studying the EU as we study federations? Looking across the range of EU activities and comparing directly to Canada, Verdun argues that while some aspects of the EU meet the criteria of a "federation" particularly when compared to the highly decentralized Canadian example, it lacks an overarching (metagovernance norm?) commitment to being a federation-it is a federation without an ideology of "federalism".

\section{Conclusions}

While the articles included in this thematic issue are disparate, both in terms of the scope of what they cover and their theoretical commitments, they nonetheless illustrate how complimentary much of the work on contemporary global politics is; no matter where it emerges from. The focus on norms and institutional arraignments runs throughout these papers. There is also huge potential for cross fertilization in these works. 
While the existing IR constructivist literature has made large strides on focusing our attention on norms, work in comparative politics has more developed ideas about institutional design-greater dialogue between these approaches would advance the global governance project.

\section{Acknowledgements}

The authors would like to thank all of those who submitted to the thematic issue and the Journal's anonymous reviewers whose contribution in this case was above and beyond what we normally ask.

\section{Conflict of Interests}

The authors declare no conflict of interests.

\section{References}

Barnett, M., \& Finnemore, M. (2004). Rules for the world: International organizations in global politics. Ithaca: Cornell University Press.

Barqueiro, C., Seaman, K., \& Towey, K. T. (2016). Regional organizations and responsibility to protect: Normative reframing or normative change? Politics and Governance, 4(3), 37-49.

Cerny, P. (1997). Paradoxes of the competition state: The dynamics of political globalization. Government and Opposition, 32(2), 251-274.

Checkel, J. (1998). The constructive turn in international relations theory. World Politics. 50. (02). 324-348

Chou, M. H., Howlett, M., \& Koga, K. (2016). Image and substance failures in regional organisations: Causes, consequences, learning and change? Politics and Governance, 4(3), 50-61.
D'Erman, V. J. (2016). Comparative intergovernmental politics: CETA negotiations between Canada and the EU. Politics and Governance, 4(3), 90-99.

Finbow, R. (2016). Restructuring the state through economic and trade agreements: The case of investment disputes resolution. Politics and Governance, 4(3), 62-76.

Finnemore, M., \& Sikkink, K. (1998). International norm dynamics and political change. International Organization, 52(4), 887-917.

Holzscheiter, A., Bahr, T., \& Pantzerhielm, L. (2016). Emerging governance architectures in global health: Do metagovernance norms explain interorganisational convergence? Politics and Governance, 4(3), 5-19.

Jessop, B. (2014). Metagovernance. In M. Bevir (Ed.), The SAGE handbook of governance (pp. 106-123). London: SAGE.

McBride, S. (2006). Reconfiguring sovereignty: NAFTA chapter 11 dispute settlement procedures and the issue of public-private authority. Canadian Journal of Political Science, 39 (4), 755-775.

Rapkin, D. P., Strand, J. R., \& Trevathan, M. W. (2016). Representation and governance in international organizations. Politics and Governance, 4(3), 77-89.

Verdun, A. (2016). The federal features of the EU: Lessons from Canada. Politics and Governance, 4(3), 100-110.

Wiener, A. (2016). Contested norms in inter-national encounters: The 'Turbot War' as a prelude to fairer fisheries governance. Politics and Governance, 4(3), 20-36.

Wiener, A., \& Puetter, U. (2009). The quality of norms is what actors make of it: Critical-constructivist research on norms. Journal of International Law and International Relations, 5(1), 1-15.

\section{About the Authors}

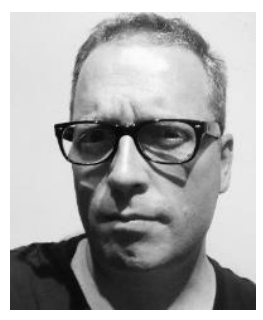

Russell Alan Williams is an associate professor of political science at Memorial University. His research focuses on the intersection between international political economy and public policy in the areas of financial services regulation, the management of trade disputes, and climate change policy. He has numerous publications, including articles in the Journal of Public Policy, Review of Policy Research, the International Journal of Public Sector Management, Canadian Foreign Policy, Global Social Policy and the American Review of Canadian Studies.

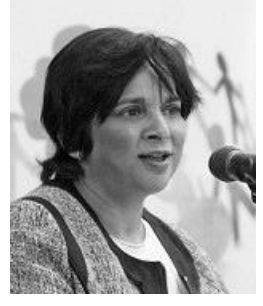

Reeta Chowdhari Tremblay is Professor of Comparative Politics and Global South in the department of Political Science at the University of Victoria. Her major areas of research are identity-based politics and secessionist movements (Kashmir) in South Asia, the politics of subaltern resistance and accommodation in post-colonial societies, democracy and governance, and comparative federalism. She has authored or co-authored six books and several articles and reviews. Her recent publications include: Kashmir's Contentious Politics: The More Things Change, the More They Stay the Same (2015); "Beyond Parochialism and Domestic Preoccupation: The Current State of Comparative Politics in Canada" (2013) and "Labor Migration, Citizenship, and Social Welfare in China and India" (2013). 